\title{
КОМПЛЕКСНА ОЦІНКА ПОКАЗНИКІВ БІЛКІВ ГОСТРОЇ ФАЗИ ЗАПАЛЕННЯ В ДІАГНОСТИЦІ Й ПРОГНОЗУВАННІ ГНІЙНО-НЕКРОТИЧНИХ УСКЛАДНЕНЬ ЦУКРОВОГО ДІАБЕТУ
}

\begin{abstract}
Резюме. Цукровий діабет (ЦД) становить серйозну медико-соціальну проблему. Від нього страждають 415 млн осіб (кожен 11-й), з тенденцією до зростання чисельності в 2040 р. до 642 млн (майже 10 \% від загальної популяції). В Україні поширеність ЦД на початок 2015 р. становила 2,8 \%. Одним із ускладнень ЦД є синдром діабетичної стопи (СДС), який на сьогодні розглядають як одне з найтяжчих ускладнень, і є результатом розвитку полінейропатії, остеоартропатії, ангіопатії.

Мета дослідження - підвищити ефективність лікування хворих із гнійно-некротичними формами цукрового діабету.

Матеріали і методи. Під нашим спостереженням перебували 116 пацієнтів із синдромом діабетичної стопи (СДС) у віці в середньому $(63,3 \pm 7,1)$ р. Критеріями включення в дослідження були відсутність адекватного для реваскуляризації периферичного судинного русла (на основі ком'ютерної ангіограсрії) і наявність гнійно-некротичного процесу на стопі. Надана письмова згода на участь у дослідженні.

Результати досліджень та їх обговорення. Вираження деструкції тканин стопи, відповідно до класифрікації P. M. Wagner (1979), у 74 \% відповідала 3-4 стадіям. При госпіталізації у 78 \% хворих була тривала декомпенсація цукрового діабету (Цд)

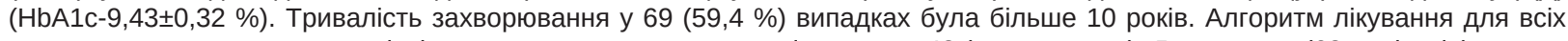
хворих включав малу ампутацію і комплексне консервативне лікування - 48 (перша група). Друга група (68 пацієнтів), яким в доповнення було проведено катетеризацію нижньої надчеревної артерії і остеоперфорацію. При госпіталізації транскутанна напруга кисню $\mathrm{TcpO}_{2}$ в середньому становила $(15,1 \pm 6,3)$ мм рт. ст. Концентрація С-реактивного білка (СРБ) була підвищена у 98,9 \% пацієнтів і в середньому склала $(12,1 \pm 1,9)$ мг/л $(0-24,0$ мг/л), (p<0,1). У 64,3 \% хворих визначено підвищення рівня фрібриногену в середньому до 5,8 г/л $(4,7-7,0$ г/л), (р<0,01). У другій групі спостереження на 10 добу відмічено наростання показників $\mathrm{TcpO}_{2}$ до $(28,3 \pm 9,3)$ мм рт. ст., зменшення набряку тканин з тенденцією рани до загоєння. Результати вмісту фрі-

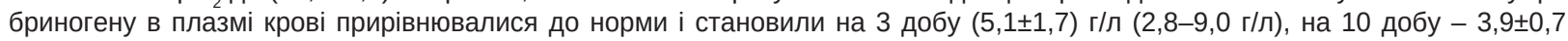
$(2,4-3,1)$ при $($ р<0,1). Показники СРБ складали на 3 і 10 доби $(0 \pm 1,1)$ мг/л $(0-12$ мг/л).

Висновки. При відсутності можливості проведення реконструктивних операцій із відновленням кровопостачання альтернативою є катетеризація нижньої надчеревної артерії і остеоперфорація. Найбільшою чутливістю і специфічністю характеризується показник концентрації СРБ і фрібриногену, що вказує на їх діагностичну значимість при гнійно-некротичних процесах на тлі цукрового діабету. Концентрація СРБ і фібриногену в крові підвищується пропорційно до тяжкості запального процесу і відповідає ступеню загоєння рани.
\end{abstract}

Ключові слова: цукровий діабет; гнійно-некротичні ускладнення; остеоперфорація; С-реактивний білок; фібриноген.

ВСтуп Цукровий діабет (ЦД) становить серйозну медико-соціальну проблему. [1]. Від нього страждають 415 млн осіб (кожен 11-й), з тенденцією до зростання чисельності в 2040 р. до 642 млн (майже 10 \% від загальної популяції) [2]. В Україні поширеність ЦД на початок 2015 р. становила 2,8 \% [3]. Одним із ускладнень ЦД є синдром діабетичної стопи (СДС), який на сьогодні розглядають як одне з найтяжчих ускладнень [4], і $є$ результатом розвитку полінейропатії, остеоартропатії, ангіопатії [5]. Природний перебіг ішемії нижніх кінцівок у хворих на цукровий діабет пов'язаний з атеросклеротичним процесом, що характеризується раннім початком і швидким прогресуванням, відсутністю специсрічного розподілу за статевою ознакою, мультисегментарністю і симетричністю ушкоджень дистально розташованих артерій середнього і дрібного калібру, високою смертністю. Рутинними неінвазивними методами оцінки тяжкості ішемічного ушкодження кінцівки $€$ транскутанна оксиметрія $[6,7]$.

Гострофразні білки - це білки коагуляції (фрібриноген, протромбін) транспортні білки (С-реактивний білок, церулоплазмін та ін.). Нормальні значення СРБ індивідуальні й варіюють від 1 до 6 мг/л. При запальних процесах рівень їх зростає до 100 разів у перші 6-12 год [8]. Фібриноген $€$ розчинним попередником фрібрину - головного компонента кров'яного згустка. Рівні фрібриногену різко зростають в крові при запаленні або ушкодженні тканини. Ресеренсні значення 1,8-3,5 г/л [9].

Згідно з оновленим Міжнародним консенсусом із синдрому діабетичної стопи (Гаага, травень 2015), лікування даної патології повинно полягати у наступному - мультидисциплінарний підхід із розвантаженням ураженої кінців- ки, відновленням кровопостачання, лікування запального процесу, метаболічний контроль, місцеве лікування виразки, навчання хворого та родичів пацієнта правил догляду за виразкою, профілактика рецидиву виразки [10].

Метою дослідження було підвищення ефективності лікування хворих із гнійно-некротичними фрормами цукрового діабету.

МАТЕРІАЛИ І МЕТОДИ У клініці хірургї̈ ЦМКЛ м. Івано-Франківська, в період з 2015 до 2017 р. під нашим спостереженням перебували 116 пацієнтів із СдС у віці в середньому $(63,3 \pm 7,1)$ р. 3 них чоловіків було $44 \%$, жінок - 56 \%. Переважали пацієнти 3 ЦД 2 типу (100\%). У 18 \% хворих діагноз ЦД було встановлено вперше. На момент госпіталізації у 78 \% хворих була тривала деком-

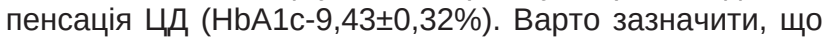
тривалість захворювання із нейроішемічною фрормою в 69 (59,4 \%) випадках була більше 10 років.

Критеріями включення в дослідження були відсутність адекватного для реваскуляризації периферичного судинного русла (на основі ком'ютерної ангіографрії) і наявність гнійно-некротичного процесу на стопі. Надана письмова згода на участь у дослідженні. Вираження деструкції тканин стопи, відповідно до класифрікації Р. M. Wagner (1979), у 74 \% відповідала 3-4 стадіям.

У дослідженні критеріями виключення були хворі, яким показана висока ампутація нижньої кінцівки, перисрерична форма облітеруючого атеросклерозу без цукрового діабету, термінальні стани, пацієнти, яким в анамнезі було проведено катетеризацію нижньої надчеревної артерії на стороні ураження, гепатит А, B, C, СНІД, відкрита форма туберкульозу легень, онкологічні захворювання. 
План дослідження відповідав етичним нормам і нормативним документам, схвалений етичною комісією ЦМКЛ м. Івано-Франківська і полягав у біохімічному дослідженні крові, вимірюванні транскутанної напруги кисню, дуплексного обстеження судин кінцівок, КТ, ангіографрії. Забір крові на дослідження проводили при госпіталізації на 3 і 10 доби.

Алгоритм лікування для всіх хворих включав малу ампутацію і комплексне консервативне лікування - 48 (перша група). Друга група (68 хворих), яким в доповнення було проведено катетеризацію нижньої надчеревної артерії і остеоперфорацію. Групи були зіставні за діагнозом, віком і ускладненнями.

РЕЗУЛЬТАТИ ДОСЛІДЖЕНЬ ТА ЇХ ОБГОВОРЕННЯ За даними транскутанної оксиметрії при госпіталізації, середній рівень ТсрО 2 склав $(15,1 \pm 6,3)$ мм рт. ст.

При госпіталізації було оцінено результати загального аналізу крові: лейкоцитоз було виявлено у 67,7 \%

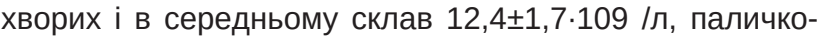
ядерних із зсувом вліво відмічено у 38,5 \% пацієнтів (кількість нейтрофрілів склала в середньому $(79,9 \pm 6,6) \%$, паличкоядерних нейтросрілів - $(10,6 \pm 2,1) \%$. Збільшення ШОЕ в середньому до $(28,4 \pm 0,7)$ мм/год $(22-57$ мм/год) відзначено у 61,5 \% хворих. Концентрація СРБ була підвищена у 98,9 \% пацієнтів і в середньому склала $(12,1 \pm 1,9) \mathrm{мг/л} \mathrm{(0-24,0} \mathrm{мг/л),} \mathrm{(р<0,1).} \mathrm{У} \mathrm{64,3} \mathrm{\%} \mathrm{хворих}$ визначено підвищення рівня фрібриногену в середньому до 5,8 г/л (4,7-7,0 г/л), (р<0,01). Поєднання змін 3 і більше маркерів запалення крові відзначено у 96 \% хворих.

При наближенні до норми показників лейкоцитарної срракції і шОЕ на 3 і 10 доби залишалися значимо вищі рівні СРБ у хворих першої групи відносно третьої $(p<0,01)$.

\section{СПИСОК ЛІТЕРАТУРИ}

1. Trends in prevalence and control of diabetes in the United States, 1988-1994 and 1999-2010 / E. Selvin, C. M. Parrinello, D. B. Sacks, J. Coresh // Ann. Intern. Med. - 2014. - Vol. 160 (8). - P. 517-525. doi: 10.7326/M13-2411.

2. International Diabetes Federation. IDF Diabetes Atlas. 7th Edition [Internet]. Brussels, Belgium: IDF; 2015. Available from http:// www.diabetesatlas.org/ Accessed 20 February 2016.

3. Довідник основних показників діяльності ендокринологічної служби України за 2014 рік // Ендокринологія. - 2015. - Дод. 1, T. 20, № 1. - 38 c.

4. Tuttolomondo A. Diabetic foot syndrome as a possible cardiovascular marker in diabetic patients / A. Tuttolomondo, C. Maida, A. Pinto // J. Diabetes Res. - 2015. - № 10. - P. 1955-2015.

5. Prevention of diabetic foot ulcer / B. Iraj, F. Khorvash, A. Ebneshahidi, G. Askari // Int. J. Prev. Med. - 2013. - Vol. 4. P. $373-376$.

Рівні СРБ на 3 і 10 доби в першій групі становили $(12,0 \pm 1,8)$ мг/л (0-12 мг/л), при показниках фрібриногену - $(6,1 \pm 1,7)$ г/л $(5,0-17,1),(4,2 \pm 0,65)$ г/л $(4,0-4,8),(p<0,01)$ відповідно. Транскутанна напруга кисню ТсрО 2 становила в середньому $(23,6 \pm 3,5)$ мм рт. ст. Отримані результати вказують на відносне наповнення мікроциркуляторного русла при пролонгації запального процесу.

У другій групі спостереження при наростанні показників $\mathrm{TcpO}_{2}$ до $(28,3 \pm 9,3)$ мм рт. ст. відмічено зменшення набряку тканин із тенденцією рани до загоєння. Результати вмісту фрібриногену в плазмі крові мали тенденцію наближення до норми і становили на 3 добу $(5,1 \pm 1,7)$ г/л $(2,8-$

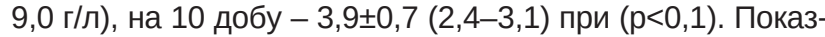
ники СРБ складали на 3 і 10 доби $(0 \pm 1,1)$ мг/л (0-12 мг/л)

Середні терміни стаціонарного лікування і загоєння ран стопи склали в першій групі $(15,0 \pm 6,7)$ доби (6-

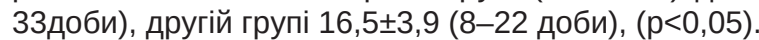

ВИСНОВКИ 1. При відсутності можливості проведення реконструктивних операцій із відновленням кровопостачання альтернативою $€$ катетеризація нижньої надчеревної артерії і остеоперфорація.

2. Найбільшою чутливістю і специфрічністю характеризується показник концентрації СРБ і фрібриногену, що вказує на їх діагностичну значимість при гнійно-некротичних процесах на тлі цукрового діабету.

3. Концентрація СРБ і фрібриногену в крові підвищується пропорційно до тяжкості запального процесу і відповідає ступеню загоєння рани.

4. Кореляція між поєднаними маркерами гострофразних білків крові й клінічними симптомами дозволяє прогнозувати перебіг гострого гнійного запалення при гнійнонекротичних формах цукрового діабету.

6. Baumann F. Infrapopliteal lesion morphology in patients with critical limb ischemia: implications for the development of antirestenosis technologies / F. Baumann, R. P. Engelberger, T. Willenberg [et al.] // J. Endovasc Ther. - 2013. - Vol. 20 (2). P. 149-156. doi: 10.1583/1545-1550-20.2.149.

7. Inter-Society Consensus for the Management of Peripheral Arterial Disease (TASC II) / L. Norgren, W. R. Hiatt, J. A. Dormandy [et al.] // J. Vasc. Surg. - 2007. - Vol. 45 (Suppl. S). - P. 5-67.

8. Wilson D. D. McGraw-Hill Manual of laboratory and diagnostic tests / D. D. Wilson // McGraw-Hill Medical, 2007. - 608 p.

9. Туйсин С. Р. Лабораторные маркеры развития гнойно-септических осложнений в хирургии / С. Р. Туйсин // Соврем. наукоёмк. технол. - 2012. - № 4. - С. 21-23.

10. Diabetic foot complications and their risk factors from a large retrospective cohort study / K. Al-Rubeaan, M. Al Derwish, S. Ouizi [et al.] // PLoS One. - 2015. - Vol. 10 (5). - P. e0124446. doi: 10.1371/journal.pone.0124446.

@OO. V. Pyptiuk, S. M. Vasyluk, V. O. Pyptiuk, S. B. Telemukha Ivano-Frankivsk National Medical University COMPLEX ASSESSMENT OF PROTEIN INDICATORS OF ACUTE PHASE INFECTION IN DIAGNOSTICS AND PROMOTION OF MUTUAL-NECROTIC COMPLICATIONS OF DIABETES MELLITUS

Summary. Diabetes mellitus (DM) represents a serious medical and social problem. 415 million people (every 11 th) suffers from it, with a tendency to increase in size in 2040 up to 642 million (almost $10 \%$ of the total population). In Ukraine, the prevalence of diabetes at the beginning of 2015 was $2.8 \%$. One of the complications of diabetes is the diabetic foot syndrome (DFS), which today is considered as one of the most serious complications, and is the result of the development of polyneuropathy, osteoarthropathy, angiopathy. 
The aim of the study - increasing effectiveness of treatment of patients with purulent-necrottic form of diabetic foot.

Materials and Methods. We observed 116 patients with DFS aged $63.3 \pm 7.1$ years old. Inclusion criteria's was absence of adequate for revascularization peripheral arterial flow (based on contrast computed tomography angiograms), presence of purulent - necrotic process on foot and signed informed consent.

Results and Discussion. Destruction stage on foot was 3-4 by P. M. Wagner (1979) classification in $74 \%$ cases. At the moment of hospitalization $78 \%$ of patients have long term decompensation of DM (HbA1c-9.43 $\pm 0.32 \%)$. Duration of illness in 69 (59.4 \%) cases was longer than 10 years. In algorithm of treatment for all patients included small amputation and complex medication treatment - 48 (I group). In 68 cases (II group) catheterization of a.epigastrica and osteoperforation of tibia was added. At the moment of hospitalization: usage of transcutaneous oximetry shows average $\mathrm{TcpO}_{2} 15.1 \pm 6.3 \mathrm{~mm}$.hg. Concentration of C-reactive protein was increased in $98.9 \%$ cases and in average was $12.1 \pm 1.9 \mathrm{mg} / \mathrm{l}(0 / 24.0 \mathrm{mg} / \mathrm{l})(\mathrm{p}<0.1)$. In $64.3 \%$ patients increasing of fibrinogen range was found $-5.8 \mathrm{~g} / \mathrm{l}(4.7 / 7.0 \mathrm{~g} / \mathrm{l})$, $(p<0.01)$. On 10 day after operation in group II we saw the increasing of average ranges of $\mathrm{TcpO}_{2}$ up to $28.3 \pm 9.3 \mathrm{~mm}$.hg., swallow decreasing and tendency to wound healing. Results of fibrinogen range in blood plasma were equate to normal and was $5.1 \pm 1.7 \mathrm{~g} / \mathrm{l}(2.8 / 9.0 \mathrm{~g} / \mathrm{l}) \mathrm{on}$ the third day and $3.9 \pm 0.7(2.4 / 3.1)$ on a $10^{\text {th }}$ day $(p<0.1)$. Ranges of $C$-reactive protein on third and tenth day was $0 \pm 1.1 \mathrm{mg} / \mathrm{l}(0 / 12 \mathrm{mg} / \mathrm{l})$.

Conclusions. In case of possibility absence to perform the reconstructive operation with renovation of arterial flow - alternative is to perform the catheterization of a.epigastirica inferior an osteoperforation of tibia. The greatest sensitivity and specificity is characterized the range of C-reactive protein and fibrinogen that shows their diagnostic significance in patients with purulent - necrotic DFS. Concentration of C-reactive protein increases proportionally to severity of illness and response to wound healing.

Key words: diabetes mellitus; purulent-necrotic complications; osteoporphonation; C reactive protein; fibrinogen.

(сА. В. Пиптюк, С. М. Василюк, В. А. Пиптюк, С. Б. Телемуха

Ивано-Франковский национальный медицинский университет

\section{КОМПЛЕКСНАЯ ОЦЕНКА ПОКАЗАТЕЛЕЙ БЕЛКОВ ОСТРОЙ ФАЗЫ ВОСПАЛЕНИЯ В ДИАГНОСТИКЕ И ПРОГНОЗИРОВАНИИ ГНОЙНО-НЕКРОТИЧЕСКИХ ОСЛОЖНЕНИЙ САХАРНОГО ДИАБЕТА}

Резюме. Сахарный диабет (СД) представляет серьезную медико-социальную проблему. От него страдают 415 млн человек (каждый 11-й), с тенденцией к росту численности в 2040 гг. до 642 млн (почти $10 \%$ от общей популяции). В Украине распространенность СД на начало 2015 г. составляла 2,8 \%. Одним из осложнений СД является синдром диабетической стопы (СДС), который сегодня рассматривают как одно из самых тяжелых осложнений, и является результатом развития полинейропатии, остеоартропатии, ангиопатии.

Цель исследования - повышение эфрфективности лечения больных с гнойно-некротическими формами сахарного диабета. Материалы и методы. Под нашим наблюдением находились 116 пациентов с синдромом диабетической стопы (СДС) в возрасте в среднем $(63,3 \pm 7,1)$ г. Критериями включения в исследование были отсутствие адекватного для реваскуляризации периферического сосудистого русла (на основании компъютерной ангиографии) и наличие гнойно-некротического процесса на стопе. Предоставлено письменное согласие на участие в исследовании.

Результаты исследований и их обсуждение. Выраженность деструкции тканей стопы, в соответствии с классификацией P. M. Wagner (1979) у 74 \% отвечала 3-4 стадиям. При госпитализации у 78 \% больных была длительная декомпенсация СД

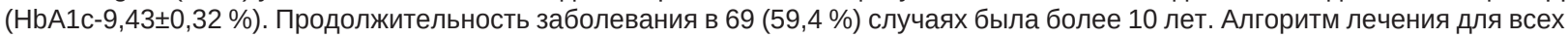
больных включал малую ампутацию и комплексное консервативное лечение - 48 (первая группа). Вторая группа (68 больных), которым в дополнение было проведено катетеризацию нижней надчревной артерии и остеоперфорация. При госпитализации $\mathrm{TcpO}_{2}$ в среднем составил $(15,1 \pm 6,3)$ мм рт. ст. Концентрация С-реактивного белка (СРБ) была повышена в $98,9 \%$ пациентов и в среднем составила $(12,1 \pm 1,9)$ мг/л $(0-24,0$ мг/л), ( $<<0,1)$. В 64,3 \% больных определено повышение уровня фрибриногена в среднем до 5,8 г/л (4,7-7,0 г/л), (p<0,01). Во второй группе наблюдения на 10 сутки отмечено нарастание показателей ТсрО до $(28,3 \pm 9,3)$ мм рт. ст., уменьшение отека тканей с тенденцией раны до заживления. Результаты содержания фрибриногена

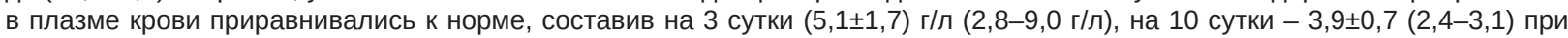
$(\mathrm{p}<0,1)$. Показатели СРБ составляли на 3 и 10 сутки $(0 \pm 1,1)$ мг/л (0-12 мг/л).

Выводы. При отсутствии возможности проведения реконструктивных операций с восстановлением кровоснабжения альтернативой является катетеризация нижней надчревной артерии и остеоперфорация. Наибольшей чувствительностью и специфричностью характеризуется показатель концентрации СРБ и фибриногена, что указывает на их диагностическую значимость при гнойно-некротических процессах на фоне сахарного диабета. Концентрация СРБ и фрибриногена в крови повышается пропорционально тяжести воспалительного процесса и соответствует степени заживления раны.

Ключевые слова: сахарный диабет; гнойно-некротические осложнения; остеоперфорация; С-реактивный белок; фрибриноген. 